\title{
THE NUTRIENT COMPOSITION OF SOUTH AFRICAN MUTTON
}

\author{
J. Sainsbury - University of Pretoria, South Africa \\ H.C. Schönfeldt - University of Pretoria, South Africa \\ S.M. van Heerden - Agricultural Research Council: Animal Production, South Africa
}

Tel: 0825672578

Fax: 0865504355

e-mail: jeanine.sainsbury@gmail.com

\begin{abstract}
Dorper and Mutton Merino carcasses of the $\mathrm{C}$ age group with a fat code $2( \pm 7 \% \mathrm{SCF})$ from three main production areas (Karoo, Kalahari and Ermelo) in South Africa were analysed in this study. The physical composition of each cut differed dramatically from the other cuts. The differences between the ten wholesale cuts when comparing the two breeds, are small, and only five cuts differed significantly on one trait. The right sides of the carcasses were used to determine the nutrient and physical (carcass) composition of each raw cut as well as for the whole carcass by calculation. Three cuts (shoulder, loin and leg) from the left side were cooked in order to determine the nutrient composition thereof. Cooking increased the protein and cholesterol concentrations of the cooked cuts. Iron content was higher in the cooked loin and leg but decreased in the cooked shoulder during cooking. According to nutrient density, mutton is a good source of protein, iron and B vitamins and supply more than $25 \%$ of RDA $/ 100 \mathrm{~g}$ of vitamin B12 when cooked.
\end{abstract}

Key Words: Nutrient composition, South African mutton, Dorper, Merino, Nutrient density 


\section{INTRODUCTION}

Nutrition plays an integral role in the optimal functioning of the body compared to malnutrition (including under nutrition and over nutrition) that is a health impairment resulting from a

deficiency, excess or imbalance of nutrients (Robinson, 1978). Most developing countries are faced with the double burden of persisting under nutrition as well as the growing epidemic of obesity and non-communicable diseases such as cancer and heart disease and South Africa is no exception (Labadarios \& Oelofse, 2000). Information to link nutrition and chronic diseases is necessary to inform the consumer on healthier food choices as consumers are becoming more health conscious and are increasingly focusing on food safety as well as their eating habits and nutrient intake (Garnier et al., 2002). The consumers' involvement influences the whole food chain, agriculture and science (Garnier et al., 2002). Food choices can have a positive or negative influence on the person's health status (Kruger et al., 2003). Some diseases commonly found in South Africa are related to malnutrition (under- and overnutrition) and thus emphasising the need for greater knowledge on the composition of food (Johnson, 1987). Detailed knowledge on the composition of foods is essential to understand the function of nutrients in the diet. The assessment of dietary exposure is critical for the interpretation of the relationship between nutrition and health (Deharveng et al., 1999). Food composition tables give information on the portion, composite sample, collection and analysis of the composition of foods (Miller \& Payne, 1961; Southgate, 1998) and can be used to evaluate a person's food intake and compare it to the Recommended Dietary Allowance (RDA) (Whitney \& Rolfes, 2002).

Many countries use one national food composition table that contains food commonly eaten in the country. Some of the data analysed in one country is also used in the food composition tables 
of other countries. Problems arise where the different countries use different methods to analyse nutritional composition as well as different measuring units and cooking methods. Due to difference in definitions, methods and methods of analysis it is obvious that these food composition tables are not international and it is therefore important that each country has their own food composition tables (Deharveng et al., 1999). The first food composition tables for South African foods were compiled by the Research Institute for Nutritional Diseases (NRIND) in 1991 (Langenhoven et al., 1993). Current South African food composition tables are compiled by the Medical Research Council (MRC) (Langenhoven et al., 1993). However, only 41\% of the data in these tables are currently derived from South African foodstuffs (Sayed et al., 1999) with the remaining data obtained mainly from American and English composition tables.

Previous nutrition data on mutton for South African food composition tables was borrowed from the UK food composition tables (Langenhoven et al., 1993) but the latest update on mutton and lamb that appear in the MRC's food composition tables of 1999 are derived from the United States Department of Agriculture (USDA, 1989) database (Sayed et al., 1999). Although sheep in South Africa originated from international breeds the nutritional composition of mutton various greatly between countries (Van Heerden et al., 2007) due to different reasons, for instance meat products are dissected into different primal cuts in each country, thereby influencing the composition of meat cuts (Schönfeldt, 1998). Amino acids for example differ between different parts of the carcasses and different cutting methods may influence the amino acids detected (Lawrie, 1998). Genetic and environmental factors are the main factors affecting the quality and nutrient content of meat (Okeudo \& Moss, 2005). Greenfield and Southgate (2003) further states that differences in climate as well as soil content between the countries may also influence the nutrient content of the animals' feed and thus the nutrient content of the 
animals' meat. According to Givens (2005) the fatty acid composition of animal products are not fixed and can be altered in response to changes in the diet of the productive animals. Postmortem factors that differ among countries, such as fat trim levels and cooking can also cause changes in nutrient composition (Jamora \& Rhee, 1998). Jamora and Rhee (1998) further explains that cooking lead to moisture loss and thus an increase in concentration of some nutrient and decrease in heat-labile nutrients.

Van Heerden et al. (2007) reports that SA lamb contains on average $40 \%$ less fat than that published in the National Food Consumption Tables by the Medical Research Council in 1999. The fat content of lamb in the UK has decreased with $10 \%$ over the last twenty years. Therefore the need for nutrient composition data of South African (SA) meat was identified by the Red Meat Producers Organisation (RPO) as a priority.

\section{MATERIALS AND METHODS}

\subsection{Sampling}

Mutton carcasses from the $\mathrm{C}$ age class and fatness level 2 were selected from the meat industry as it represents South African mutton purchased by the consumer. The South African Red Meat Classification System for lamb and sheep uses the main characteristics of beef, mutton, lamb and goat to classify the carcasses in order to make the purchase of red meat as simple as possible for sonumers. The main characteristics used to classify mutton for this study are the age of the animal

and the fatness of the carcass. The age classes are known as: A (youngest animals ( 0 incisors)), AB (older animals (1-2 incisors)), B (even older animals; (3-6 incisors), and C (oldest animals 
(7-8 incisors)). The fatness classes are known as class zero (no fat) to class 6 (excessively over fat) (SAMIC s.a.).

The $\mathrm{C} 2$ mutton carcasses were obtained through stratified sampling where food is selected, taking into account the most important causes of variation. The meat samples, incorporated in the study, comprised of the two most commonly consumed breeds Dorper $(n=9)$ and Mutton Merino $(n=9)$ carcasses which were obtained from abattoirs that draw mutton from the three main production areas in South Africa namely the Karoo, Kalahari and Ermelo districts. The sheep were slaughtered using standard commercial procedures during four consecutive weeks. The carcasses were classified according to the South African classification system by a qualified classifier at the abattoirs. Selected carcasses were transported in a refrigerated truck $\left(4-6{ }^{\circ} \mathrm{C}\right)$ to the Meat Industry Centre of the then ARC-ANPI, Irene. Upon arrival, all the carcasses were weighed, covered with plastic wrap to prevent moisture loss and chilled at $4{ }^{\circ} \mathrm{C}$ overnight and dissected the following day. The mutton carcasses consisted of the skinned, eviscerated body from which the head, feet, kidney and kidney fat were removed.

Three cuts (shoulder, leg and loin from the left side of the carcass), representing the most commonly consumed cuts, were used to determine the cooked proximate analysis, physical composition and nutrient composition. These cuts (leg, loin, shoulder) were cooked according to standardized moist and dry heat cooking methods in identical Mielé ovens at $163{ }^{\circ} \mathrm{C}$ to an internal temperature of $73{ }^{\circ} \mathrm{C}$ measured in the geometrical centre of the cut (AMSA, 1995). The raw and cooked nutrient data of the three cuts was compared based on the assumption, (Kirton et al., 1962) that the chemical composition of the two sides is similar or almost identical. 


\subsection{Physical dissection}

Carcasses were weighed prior to being divided into the respective wholesale cuts. A trained deboning team were responsible for the physical dissection. Carcasses were sectioned down the vertebral column with a band saw, with each side then subdivided into the following 10 primal cuts: neck, thick rib, flank, shoulder, breast, rib, loin, chump, leg and shanks. For each cut of the right sides of the carcasses, the \% meat, subcutaneous fat and bone content were determined, in order to calculate carcass composition. Therefore the cuts were divided into three parts namely meat, bone and subcutaneous fat, in an environmentally controlled abattoir at $6^{\circ} \mathrm{C}$ by a trained de-boning team. The wholesale cuts of the left sides of the carcasses were vacuumed packed and frozen till required for cooked analysis.

\subsection{Proximate analyses}

Proximate analysis (fat, moisture, protein, ash) were done on the 10 raw wholesale cuts. Due to limited funding, proximate analysis was done on only three cooked cuts namely the leg, loin and shoulder cuts. All the raw ( $\mathrm{n}=10$ cuts) and cooked $(\mathrm{n}=3)$ physical dissected meat (muscle + intramuscular fat) and fat respectively were cubed, thoroughly mixed and then minced first through a $5 \mathrm{~mm}$ and then through a $3 \mathrm{~mm}$ mesh plate. $300 \mathrm{~g}$ sample of meat (muscle + intramuscular fat) and subcutaneous fat respectively were further homogenized with an Ultra Turrax T25 homogenizer after mincing to ensure a proper homogenized sample. Samples were vacuumed packed and frozen, prior to being freeze-dried.

\subsection{Nutrient analyses}

In order to comply with the new Draft Regulations (2004) relating (http://www.doh.gov.za/department/dir_foodcontr.html), to the Labelling and Advertising of 
Foodstuffs as part of the Foodstuffs, Cosmetics and Disinfectants Act, 1972, it is proposed that a composite of three carcasses be pooled and used as a basis of the study. The use of composite samples for analysis rather than individual samples is justified because of funding constraints and has been an accepted approach in food composition studies (Greenfield and Southgate, 2003). Therefore the samples analysed for this purpose are those of the 3 cuts (leg, loin, shoulder) of the C2 class. However, care was taken in the design to ensure statistical reliability of the data.

A composite sample ( 3 carcasses of 1 age group, 1 fat code, 2 breeds, and 3 cuts), of raw (left sides) and cooked (right sides) meat and subcutaneous fat were analysed for nutrient content. All foods vary in nutrient composition and its contribution of nutrients to the diet, therefore only the nutrients in meat that are known to be a significant source were analysed.

\section{STATISTICAL ANALYSIS}

The experiment was designed as a completely randomized design (CRD). Analysis of variance (ANOVA) was used to test for differences between mutton from 3 areas and 2 breeds, as well as the area $\mathrm{x}$ breed interaction. The data was acceptably normal with homogeneous treatment variances. Treatment means were separated using Fisher's protected t-test least significant difference (LSD) at the 5\% level of significance (Snedecor \& Cochran, 1980). Data were analysed using the statistical program GenStat (2003).

Sources of variation for all the nutrient data collected were investigated by ANOVA (GenStat, 2003). For any significant difference found for any variate, Bonferroni multiple comparison tests were performed. The Bonferroni test is stricter than the ANOVA test, therefore it is not necessarily true that $p \geq 0,05$ will identify differences between means if tested according to the 
Bonferroni test method. A correlation matrix was constructed to test for correlation between the different variables (GenStat, 2003).

\section{RESULTS AND DISCUSSION}

\subsection{Nutrient composition for raw and cooked $100 \mathrm{~g}$ meat portion}

The mean values of the nutrient composition for raw and cooked $100 \mathrm{~g}$ meat portion of South African C2 mutton are presented in Table 1. The nutrient values of cooked mutton are more useful to the consumers than raw values (Ono et al., 1984). However, raw values are used to evaluate production and marketing effects on nutrient composition. Cooked values, on the other hand, provide information on what is actually consumed. The differences in the amount of nutrients between raw and cooked meat cuts can be used to calculate nutrient retention in the cuts (Ono et al., 1984).

Examining the nutrient differences between raw and cooked South African mutton meat, moisture, sodium, thiamine (B1) and pyridoxine (B6) are the only components that decreased significantly during the cooking process with moisture decreasing with $13 \%$. The notable decrease in thiamine and pyridoxine are probably due to the fact that these vitamins are watersoluble and were lost in the cooking losses that were not added back to the meat prior to analysis. The nutrient components protein, fat, riboflavin (B2), all fatty acids and cholesterol increased during the cooking process (Table 1). This concentration in nutrients is mainly due to the moisture loss. Jamora and Rhee (1998) emphasises that cooking lead to moisture loss and thus an increase in concentration of some nutrient and decrease in heat-labile nutrients. 
Table 1. Mean values of the nutrient composition for raw and cooked $100 \mathrm{~g}$ meat portion of South African C2 mutton.

\begin{tabular}{|c|c|c|c|c|c|}
\hline Nutrients analysed & \multicolumn{2}{|c|}{ Unit $p$-value } & SEM & $\operatorname{Raw}(n=18)$ & Cooked $(n=18)$ \\
\hline \multicolumn{6}{|c|}{ Proximate analysis: } \\
\hline Moisture & $\bar{g}$ & $<0.001$ & 0.287 & 73.9 & 64.0 \\
\hline Protein $(\mathrm{Nx} 6.25)$ & $\mathrm{g}$ & $<0.001$ & 0.232 & 20.2 & 26.3 \\
\hline Fat & $\mathrm{g}$ & $<0.001$ & 0.219 & 4.86 & 8.58 \\
\hline Ash & $\mathrm{g}$ & 0.162 & 0.028 & 1.18 & 1.12 \\
\hline Food energy & $\mathrm{kJ}$ & $<0.001$ & 8.63 & 524 & 764 \\
\hline \multicolumn{6}{|c|}{ Minerals } \\
\hline Magnesium (Mg) & $\mathrm{mg}$ & 0.731 & 0.22 & 22.7 & 22.8 \\
\hline Potassium $(\mathrm{K})$ & $\mathrm{mg}$ & 0.863 & 3.76 & 275 & 274 \\
\hline Sodium $(\mathrm{Na})$ & $\mathrm{mg}$ & $<0.001$ & 1.06 & 83.0 & 73.5 \\
\hline Zinc $(\mathrm{Zn})$ & $\mathrm{mg}$ & 0.035 & 2.17 & 3.56 & 4.25 \\
\hline Iron $(\mathrm{Fe})$ & $\mathrm{mg}$ & 0.095 & 1.192 & 2.97 & 3.26 \\
\hline \multicolumn{6}{|c|}{ Vitamins } \\
\hline Thiamine (B1) & $\mathrm{mg}$ & $<0.001$ & 0.003 & 0.04 & 0.02 \\
\hline Riboflavin (B2) & $\mathrm{mg}$ & $<0.001$ & 0.003 & 0.04 & 0.07 \\
\hline Niacin (B3) & $\mathrm{mg}$ & 0.192 & 0.114 & 4.96 & 5.17 \\
\hline Pyridoxine (B6) & $\mathrm{mg}$ & $<0.001$ & 0.015 & 0.20 & 0.11 \\
\hline Cyanocobalamin (B12) & $\mu \mathrm{g}$ & 0.004 & 0.150 & 2.37 & 3.06 \\
\hline \multicolumn{6}{|c|}{ Lipids } \\
\hline \multicolumn{6}{|c|}{ Saturated fatty acids (SFA) } \\
\hline $14: 0$ & $\mathrm{~g}$ & $<0.001$ & 0.007 & 0.12 & 0.22 \\
\hline 16:0 & $\mathrm{g}$ & $<0.001$ & 0.569 & 1.22 & 2.15 \\
\hline 18:0 & $\mathrm{g}$ & $<0.001$ & 0.055 & 0.97 & 1.91 \\
\hline 20:0 & $\mathrm{g}$ & $<0.001$ & 0.001 & 0.01 & 0.23 \\
\hline Total saturated fatty acids & $\mathrm{g}$ & $<0.001$ & 0.125 & 2.47 & 4.57 \\
\hline \multicolumn{6}{|c|}{ Monounsaturated fatty acids (MUFAs) } \\
\hline $16: 1$ & $\mathrm{~g}$ & $<0.001$ & 0.004 & 0.08 & 0.14 \\
\hline $18: \ln 9 \mathrm{t}$ & $\mathrm{g}$ & $<0.001$ & 0.006 & 0.09 & 0.20 \\
\hline $18: \ln 9 \mathrm{c}$ & $\mathrm{g}$ & $<0.001$ & 0.082 & 1.93 & 3.20 \\
\hline Total monounsaturated fatty acid & $\mathrm{g}$ & $<0.001$ & 0.094 & 2.18 & 3.67 \\
\hline \multicolumn{6}{|c|}{ Polyunsaturated fatty acids (PUFAs) } \\
\hline $18: 2 \mathrm{n} 6 \mathrm{t}$ & $\mathrm{g}$ & $<0.001$ & 0.001 & 0.02 & 0.04 \\
\hline $18: 2 \mathrm{n} 6 \mathrm{c}$ & $\mathrm{g}$ & $<0.001$ & 0.005 & 0.11 & 0.18 \\
\hline Cholesterol & $\mathrm{mg}$ & $<0.001$ & 2.160 & 47.9 & 61.20 \\
\hline
\end{tabular}




\begin{tabular}{|c|c|c|c|c|c|c|}
\hline Nutrients analysed & Unit & $\boldsymbol{p}$-value & SEM & Raw $(\boldsymbol{n}=\mathbf{1 8})$ & Cooked $(\boldsymbol{n}=\mathbf{1 8})$ \\
\hline \hline CLA & & 0.185 & 0.009 & 0.17 & 0.26 \\
\hline
\end{tabular}

$p$-value: $F$-probability to test for significant differences between samples. SEM: Standard Error of Means. The significance of all the variables measured for each sample was tested with split-plot analysis of variance (ANOVA), whereby the main effect of the cuts ( $n=10$ - whole plots) and treatment ( $n=18$ raw and cooked - sub-plots), WAS tested at the 5\% level of significance $(p \leq 0.05)$.

The mean values of the nutrient composition for the interaction between raw and cooked cuts are presented per $100 \mathrm{~g}$ edible portion for South African C2 mutton in Table 2. The nutrients showing the greatest differences between the three cuts (shoulder, leg and loin) for the raw and

Table 2. Mean values of the nutrient composition of three raw and three cooked cuts per $100 \mathrm{~g}$ edible portions (meat and fat) of South African C2 mutton.

\begin{tabular}{|c|c|c|c|c|c|c|c|}
\hline \multirow{2}{*}{ Nutrients analysed } & \multicolumn{4}{|c|}{ Raw cuts $(n=3)$} & \multicolumn{3}{|c|}{ Cooked cuts $(n=3)$} \\
\hline & Unit & Shoulder & Loin & Leg & Shoulder & Loin & Leg \\
\hline \multicolumn{8}{|c|}{ Proximate analysis } \\
\hline Moisture & $\mathrm{g}$ & 73.8 & 74.0 & 73.7 & 66.5 & 63.2 & 64.0 \\
\hline Protein (Nx6.25) & $\mathrm{g}$ & 20.4 & 20.7 & 20.2 & 24.9 & 26.9 & 28.7 \\
\hline Fat & $\overline{\mathrm{g}}$ & 8.85 & 8.85 & 9.24 & 11.69 & 13.21 & 9.91 \\
\hline Ash & g & 1.19 & 1.20 & \begin{tabular}{|l|}
1.18 \\
\end{tabular} & 1.25 & 1.11 & 1.12 \\
\hline Food energy (calculated) & $\mathrm{kJ}$ & 667 & 682 & 689 & 860 & 951 & 857 \\
\hline \multicolumn{8}{|c|}{ Minerals } \\
\hline Magnesium (Mg) & $\mathrm{mg}$ & 21.88 & 23.0 & 21.9 & 21.1 & 23.0 & 24.2 \\
\hline Potassium (K) & $\overline{\mathrm{mg}}$ & 255.77 & 282 & 256 & 262 & 280 & 280 \\
\hline Sodium $(\mathrm{Na})$ & $\mathrm{mg}$ & 86.87 & 85.7 & 86.9 & 74.8 & 77.6 & 68.0 \\
\hline Zinc (Zn) & $\mathrm{mg}$ & 38.78 & 3.23 & 3.88 & 4.64 & 3.72 & 4.41 \\
\hline Iron $(\mathrm{Fe})$ & $\mathrm{mg}$ & 28.01 & 2.93 & 2.80 & 2.75 & 3.23 & 3.81 \\
\hline \multicolumn{8}{|c|}{ Vitamins } \\
\hline Thiamine (B1) & $\mathrm{mg}$ & 0.05 & 0.04 & 0.04 & 0.03 & 0.03 & 0.02 \\
\hline Riboflavin (B2) & $\mathrm{mg}$ & 0.04 & 0.03 & 0.04 & 0.07 & 0.05 & 0.08 \\
\hline Niacin (B3) & $\mathrm{mg}$ & 4.75 & 5.17 & 4.95 & 4.89 & 5.43 & 5.20 \\
\hline Pyridoxine (B6) & $\mathrm{mg}$ & 0.17 & 0.23 & 0.21 & 0.09 & 0.12 & 0.11 \\
\hline Cyanocobalamin (B12) & $\mu \mathrm{g}$ & 2.68 & 2.08 & 2.35 & 3.43 & 2.60 & 3.14 \\
\hline
\end{tabular}




\begin{tabular}{|c|c|c|c|c|c|c|c|}
\hline \multirow{2}{*}{ Nutrients analysed } & \multicolumn{4}{|c|}{ Raw cuts $(n=3)$} & \multicolumn{3}{|c|}{ Cooked cuts $(n=3)$} \\
\hline & Unit & Shoulder & Loin & Leg & Shoulder & Loin & Leg \\
\hline \multicolumn{8}{|c|}{ Saturated fatty acids (SFAs) } \\
\hline $14: 0$ & $\mathrm{~g}$ & 0.25 & 0.25 & 0.26 & 0.32 & 0.37 & 0.27 \\
\hline $16: 0$ & $\mathrm{~g}$ & 2.27 & 2.27 & 2.33 & 2.97 & 3.42 & 2.49 \\
\hline 18:0 & $\mathrm{g}$ & 1.90 & 1.99 & 1.94 & 2.68 & 3.28 & 2.07 \\
\hline $20: 0$ & $\mathrm{~g}$ & 0.02 & 0.03 & 0.02 & 0.03 & 0.04 & 0.03 \\
\hline \multicolumn{8}{|c|}{ " Monounsaturated fatty acids (MUFAs) } \\
\hline $16: 1$ & $\mathrm{~g}$ & 0.15 & 0.14 & 0.16 & 0.19 & 0.20 & 0.18 \\
\hline $18: \ln 9 \mathrm{t}$ & $\mathrm{g}$ & 0.19 & 0.20 & 0.21 & 0.27 & 0.33 & 0.24 \\
\hline $18: \ln 9 \mathrm{c}$ & $\mathrm{g}$ & 3.39 & 3.30 & 3.58 & 4.41 & 4.67 & \begin{tabular}{|l|}
3.88 \\
\end{tabular} \\
\hline \multicolumn{8}{|c|}{ Polyunsaturated fatty acids (PUFAs) } \\
\hline $18: 2 \mathrm{n} 6 \mathrm{t}$ & $\mathrm{g}$ & 0.04 & 0.04 & 0.04 & 0.05 & 0.06 & 0.04 \\
\hline $18: 2 \mathrm{n} 6 \mathrm{c}$ & $\mathrm{g}$ & 0.19 & 0.17 & 0.19 & 0.23 & 0.24 & 0.21 \\
\hline Cholesterol & $\mathrm{mg}$ & 49.94 & 51.01 & 50.02 & 58.75 & 70.83 & 57.94 \\
\hline
\end{tabular}

cooked treatments were moisture, protein, fat, sodium, pyridoxine and cholesterol. As expected, moisture losses due to cooking resulted in an increase in the protein and cholesterol concentrations.

\subsection{Nutrient composition of three cuts (raw and cooked) per 100 g edible portions}

According to the results in Table 2, within the edible portion of the three raw and cooked cuts on average the moisture decreases with up to $15 \%$ during the cooking process. The loin cuts lost a higher percentage of moisture during cooking than the other cuts which may be due to the fact that the loin cut was cooked according to a dry heat cooking method while the other cuts were cooked according to a moist heat cooking method. The subcutaneous fat and intermuscular fat was combined and analysed together in this study and although the amount of fat varies between the different cuts of the animal (Latham, 1997) there are no difference in the fatty acid composition between these tissues (Juarez et al., 2007). The fat content of the loin cut increased 
with a severe $49.26 \%$ during cooking. As fat content increased during cooking, the protein content decreased per 100 g portion (Enser et al., 1998).

Of the three raw cuts, the leg had more fat $(9.2 \mathrm{~g})$ when compared to the shoulder $(8.9 \mathrm{~g})$ and the loin $(8.9 \mathrm{~g})$ cuts but had the lowest fat content in edible cooked portion. With the leg containing less than $10 \mathrm{~g}$ fat per $100 \mathrm{~g}$ edible cooked portion it qualifies for the heart foundation. In a study done by Hoke et al., (1999) it was found that there exist an inverse relationship between moisture and fat content. This fact seems to be correct for all three cuts analysed in this study. The edible portion for the cooked leg cut contains less total fat and less saturated fat than the other cuts and contains $18 \%$ less cholesterol than cooked loin cut.

Although the loin cut contained high quantities of potassium, sodium an iron, the zinc content was low when compared to the other cuts. The cooked shoulder cut contained lower amounts of most minerals (magnesium, potassium, and iron) when compared to the other cooked cuts but had high cyanocobalamin content. The cooked shoulder $(58.8 \mathrm{~g})$ and leg $(57.9 \mathrm{~g})$ cut contained significantly less cholesterol than the loin cut 70.8g). (Table 2)

\subsection{Comparison between current study and MRC food composition tables}

Results tabulated in Table 3 demonstrate that meat cuts vary in its contributions to the diet. When comparing the new food composition data for mutton (C2) from the study with the current data included in the South African food composition tales (Sayed et al., 1999) there are differences in the nutrient composition of these two sets of data, because previous data were obtained from USA Food Composition Tables. This is an agreement to Greenfield and Southgate (2003) who stated that nutritional composition data varies between different countries. 
According to Vandendriessche (2008) the main attributes of meat contributing to the negative health image is the fat level, the sodium level and the fat quality in terms of fatty acid composition with the fat content of meat remaining the biggest problem (Vandendriessche, 2008), but data showing that mutton contains $29.7 \%$ less fat may overcome this problem. Although the CLA content in the current study indicates that mutton is lower in CLA, any amount of CLA present in meat is seen as value added healthful products (Corino et al., 2003)

The vitamin and mineral content of the raw and cooked mutton (C2) from the current study is lower except for potassium, iron and vitamin B12. Cooked South African mutton (data from current study) contains $63 \%$ more iron $((3.26 \mathrm{~g}-2 \mathrm{~g}) / 3.6 \times 100 \%)$.

Table 3. Comparison of the nutrient composition for raw and cooked $100 \mathrm{~g}$ edible portion of lean mutton between the South African 1999 MRC food composition tables and the results of the current study on the $\mathrm{C} 2$ mutton.

\begin{tabular}{|c|c|c|c|c|c|c|c|}
\hline \multirow{2}{*}{ Nutrients analysed } & \multirow{2}{*}{ Unit } & \multicolumn{2}{|c|}{ Raw } & \multirow{2}{*}{$\begin{array}{c}\begin{array}{c}\text { Difference } \\
\text { between } \\
\text { studies }^{\mathrm{a}}\end{array} \\
\end{array}$} & \multicolumn{2}{|c|}{ Cooked } & \multirow{2}{*}{\begin{tabular}{|c|}
$\begin{array}{c}\text { Difference } \\
\text { between } \\
\text { studies }^{\mathrm{a}}\end{array}$ \\
\end{tabular}} \\
\hline & & $\begin{array}{l}\text { Current } \\
\text { study }^{b}\end{array}$ & $\begin{array}{c}1999 \\
\text { MRC } \\
\text { tables }^{\mathrm{c}} \\
\end{array}$ & & $\begin{array}{l}\text { Current } \\
\text { study }^{b}\end{array}$ & $\begin{array}{c}1999 \\
\text { MRC } \\
\text { tables } \\
\end{array}$ & \\
\hline \multicolumn{8}{|c|}{ Proximate analysis } \\
\hline Moisture & $\mathrm{g}$ & 73.8 & 60.7 & 13.1 & 64.6 & 57.5 & 7.06 \\
\hline Protein $(\mathrm{Nx} 6.25)$ & $\mathrm{g}$ & 20.5 & 16.9 & 3.6 & 26.8 & 25.6 & 1.23 \\
\hline Fat & $\mathrm{g}$ & 8.98 & 21.6 & -12.62 & 11.6 & 16.5 & -4.9 \\
\hline Ash & $\mathrm{g}$ & 1.19 & 0.9 & 0.29 & 1.16 & 1.0 & -.16 \\
\hline $\begin{array}{c}\text { Food energy } \\
\text { (calculated) }\end{array}$ & $\mathrm{kJ}$ & 679 & 1087 & -408 & 889 & 1046 & 157 \\
\hline \multicolumn{8}{|c|}{ Minerals } \\
\hline Magnesium (Mg) & $\mathrm{mg}$ & 22 & 22 & 0 & 23 & 24 & -1 \\
\hline Potassium $(\mathrm{K})$ & $\mathrm{mg}$ & 264 & 230 & 34 & 274 & 313 & -39 \\
\hline Sodium $(\mathrm{Na})$ & $\mathrm{mg}$ & 86.5 & 58 & 28.48 & 73.4 & 66 & 7.43 \\
\hline Zinc (Zn) & $\mathrm{mg}$ & 3.66 & 3.33 & 0.33 & 4.26 & 4.4 & -0.14 \\
\hline Iron $(\mathrm{Fe})$ & $\mathrm{mg}$ & 2.84 & 1.6 & 1.24 & 3.26 & 2 & 1.26 \\
\hline
\end{tabular}




\begin{tabular}{|c|c|c|c|c|c|c|c|}
\hline \multirow{2}{*}{ Nutrients analysed } & \multirow{2}{*}{ Unit } & \multicolumn{2}{|c|}{ Raw } & \multirow{2}{*}{$\begin{array}{c}\text { Difference } \\
\text { between } \\
\text { studies }^{\text {a }}\end{array}$} & \multicolumn{2}{|c|}{ Cooked } & \multirow{2}{*}{\begin{tabular}{|c|}
$\begin{array}{c}\text { Difference } \\
\text { between } \\
\text { studies }^{\mathrm{a}}\end{array}$ \\
\end{tabular}} \\
\hline & & $\begin{array}{l}\text { Current } \\
\text { study }^{b}\end{array}$ & $\begin{array}{c}1999 \\
\text { MRC } \\
\text { tables }^{\mathrm{c}}\end{array}$ & & $\begin{array}{l}\text { Current } \\
\text { study }^{b}\end{array}$ & $\begin{array}{c}1999 \\
\text { MRC } \\
\text { tables }\end{array}$ & \\
\hline \multicolumn{8}{|c|}{ Vitamins } \\
\hline Thiamine (B1) & $\mathrm{mg}$ & 0.04 & 0.12 & -0.08 & 0.02 & 0.1 & -0.08 \\
\hline Riboflavin (B2) & $\mathrm{mg}$ & 0.04 & 0.22 & -0.18 & 0.07 & 0.27 & -0.2 \\
\hline Niacin (B3) & $\mathrm{mg}$ & 4.96 & 6.1 & -1.14 & 5.17 & 6.6 & -1.43 \\
\hline Pyridoxine (B6) & $\mathrm{mg}$ & 0.2 & 0.13 & 0.07 & 0.11 & 0.15 & -0.04 \\
\hline $\begin{array}{c}\text { Cyanocobalamin } \\
\text { (B12) }\end{array}$ & $\mu \mathrm{g}$ & 2.37 & 2.4 & -0.03 & 3.06 & 2.6 & 0.46 \\
\hline \multicolumn{8}{|c|}{ Lipids } \\
\hline $\begin{array}{c}\text { Saturated fatty acids } \\
\text { (SFA) }\end{array}$ & $\mathrm{g}$ & 4.71 & 9.47 & -4.76 & 6.07 & 6.89 & -0.82 \\
\hline $14: 0$ & $\mathrm{~g}$ & 0.25 & 0.87 & -0.62 & 0.32 & 0.64 & -0.32 \\
\hline $16: 0$ & $\mathrm{~g}$ & 2.42 & 4.75 & -2.33 & 2.96 & 3.51 & -0.55 \\
\hline $18: 0$ & $\mathrm{~g}$ & 1.94 & 2.98 & -1.04 & 2.67 & 2.22 & 0.45 \\
\hline $20: 0$ & $\mathrm{~g}$ & 0.10 & 0 & 0.1 & 0.03 & 0 & 0.03 \\
\hline $\begin{array}{c}\text { Monounsaturated } \\
\text { fatty acids (MUFAs) }\end{array}$ & g & 3.77 & 8.86 & -5.09 & 4.79 & 6.96 & -2.17 \\
\hline $16: 1$ & $\mathrm{~g}$ & 0.15 & 0.63 & -0.48 & 0.19 & 0.48 & -0.29 \\
\hline $18: 1$ & $\mathrm{~g}$ & 3.62 & 7.96 & -4.34 & 4.60 & 6.32 & -1.72 \\
\hline $\begin{array}{c}\text { Polyunsaturated fatty } \\
\text { acids (PUFAs) } \\
\end{array}$ & $\mathrm{g}$ & 0.19 & 1.7 & -1.51 & 0.28 & 1.18 & -0.9 \\
\hline $18: 2$ & $\mathrm{~g}$ & 0.19 & 1.24 & -1.05 & 0.28 & 0.9 & -0.62 \\
\hline Cholesterol & $\mathrm{mg}$ & 50.32 & 72 & -21.68 & 62.51 & 93 & -30.49 \\
\hline
\end{tabular}

Indicates that the current study has less of the particular nutrient than the MRC-tables.

a Difference: calculated on the difference between the values of the current study and that of the 1999 MRC food composition tables (Sayed et al., 1999).

b Data from current study (Table 2).

c Sayed et al. (1999).

\subsection{Recommended Dietary Allowances}

To evaluate the nutrient contribution of mutton (C2) from this study, the RDA for males, aged 25 - 30 years (Whitney \& Rolfes, 2002), were used as the reference point (Table 4). A 100 g portion 
Table 4. Contribution of $100 \mathrm{~g}$ edible portion of cooked (deboned) meat from three $\mathrm{C} 2$ mutton cuts to the nutrient allowances (RDA values) of males, aged 25-50 years.

\begin{tabular}{|c|c|c|c|c|c|c|c|c|c|}
\hline Nutrients & $\begin{array}{c}\text { Uni } \\
t\end{array}$ & \begin{tabular}{|c||} 
RDA \\
males \\
$25-$ \\
$5^{\mathbf{a}}$
\end{tabular} & $\begin{array}{c}\text { Shoulde } \\
\mathbf{r}\end{array}$ & $\begin{array}{c}\text { Shoulder \% } \\
\text { contributio } \\
\text { n }\end{array}$ & $\begin{array}{c}\text { Loi } \\
\text { n }\end{array}$ & $\begin{array}{c}\text { Loin \% } \\
\text { contributio } \\
\mathbf{n}\end{array}$ & Leg & $\begin{array}{c}\text { Leg \% } \\
\text { contributio } \\
\mathbf{n}\end{array}$ & $\begin{array}{c}\text { Average \% } \\
\text { contributio } \\
\text { n }\end{array}$ \\
\hline \multicolumn{10}{|c|}{ Proximate analysis } \\
\hline Moisture & $\mathrm{g}$ & - & 66.5 & - & 63.2 & - & \begin{tabular}{|c|}
64. \\
0
\end{tabular} & - & - \\
\hline $\begin{array}{l}\text { Protein } \\
(\mathrm{Nx} 6.25)\end{array}$ & g & 63 & 24.9 & 39.5 & 26.9 & 42.6 & \begin{tabular}{|c|}
28. \\
7
\end{tabular} & 45.6 & 42.6 \\
\hline Fat & $\mathrm{g}$ & - & 11.7 & - & 13.2 & - & \begin{tabular}{|c|}
9.9 \\
1 \\
\end{tabular} & - & - \\
\hline Ash & g & - & 1.25 & - & 1.11 & - & $\begin{array}{c}1.1 \\
2 \\
\end{array}$ & - & - \\
\hline $\begin{array}{c}\begin{array}{c}\text { Food energy } \\
\text { (calculated) }\end{array} \\
\end{array}$ & $\mathrm{kJ}$ & \begin{tabular}{|c|}
12,18 \\
0 \\
\end{tabular} & 860 & 7.06 & 950 & 7.80 & 857 & 7.04 & 7.3 \\
\hline \multicolumn{10}{|c|}{ ב Minerals } \\
\hline $\begin{array}{l}\text { Magnesium } \\
(\mathrm{Mg})\end{array}$ & $\mathrm{mg}$ & 420 & 21.1 & 5.02 & 23.0 & 5.47 & \begin{tabular}{|c|}
24. \\
2 \\
\end{tabular} & 5.76 & 5.42 \\
\hline Potassium $(\mathrm{K})$ & $\mathrm{mg}$ & 800 & 261 & 32.7 & 280. & 35.1 & $\begin{array}{c}280 \\
.\end{array}$ & 35.1 & 34.3 \\
\hline Sodium (Na) & $\mathrm{mg}$ & - & 74.8 & - & 77.6 & - & \begin{tabular}{|c|}
68. \\
0
\end{tabular} & - & - \\
\hline Zinc $(\mathrm{Zn})$ & $\mathrm{mg}$ & 15 & 4.64 & 30.9 & 3.72 & 24.8 & \begin{tabular}{|c|}
4.4 \\
1
\end{tabular} & 29.4 & 28.4 \\
\hline Iron $(\mathrm{Fe})$ & $\mathrm{mg}$ & 10 & 2.75 & 27.5 & 3.23 & 32.3 & \begin{tabular}{|c|}
3.8 \\
1 \\
\end{tabular} & 38.1 & 32.6 \\
\hline \multicolumn{10}{|c|}{ VIitamins } \\
\hline Thiamine (B1) & $\mathrm{mg}$ & 1.2 & 0.03 & 2.25 & $\mid 0.03$ & 2.08 & \begin{tabular}{|c|}
0.0 \\
2 \\
\end{tabular} & 1.42 & 1.92 \\
\hline Riboflavin (B2) & $\mathrm{mg}$ & 1.3 & 0.07 & 5.15 & 0.05 & 4.08 & \begin{tabular}{|c|}
0.0 \\
8 \\
\end{tabular} & 5.77 & 5.00 \\
\hline Niacin (B3) & $\mathrm{mg}$ & 16 & 4.89 & 30.6 & 5.43 & 33.9 & \begin{tabular}{|c|}
5.2 \\
0 \\
\end{tabular} & 32.5 & 32.3 \\
\hline Pyridoxine (B6) & $\mathrm{mg}$ & 1.7 & 0.09 & 5.12 & 0.12 & 7.18 & \begin{tabular}{|c|}
0.1 \\
1 \\
\end{tabular} & 6.47 & 6.25 \\
\hline \begin{tabular}{|c|} 
Cyanocobalami \\
$\mathrm{n}(\mathrm{B} 12)$
\end{tabular} & $\mu \mathrm{g}$ & 2.4 & 3.43 & 143 & 2.60 & 108 & \begin{tabular}{|c|}
3.1 \\
4 \\
\end{tabular} & 130. & 127 \\
\hline
\end{tabular}

- Value not available.

a Whitney and Rolfes (2002), RDA for males 25-50 years. 
of cooked shoulder, loin and leg mutton cuts provide on average $42.6 \%$ protein, $34.3 \%$ potassium and $127.4 \%$ vitamin $\mathrm{B}_{12}$ of RDA for this group of males. A $100 \mathrm{~g}$ portion provides $32.3 \%$ vitamin $\mathrm{B}_{3}, 32.6 \%$ iron, $28.4 \%$ zinc, $5.0 \%$ vitamin $\mathrm{B} 2,6.3 \%$ vitamin $\mathrm{B} 6$ and $1.9 \%$ vitamin $\mathrm{B} 1$ of the RDA.

Table 5. Indices of the diet quality for cooked, deboned South African C2 mutton cuts.

\begin{tabular}{|c|c|c|c|}
\hline \multirow[t]{3}{*}{ Nutrients } & \multicolumn{3}{|c|}{100 g edible portion } \\
\hline & \multicolumn{3}{|c|}{ " Nutrient density ${ }^{\mathrm{a}}$} \\
\hline & Loin & Leg & Shoulder \\
\hline Protein & 5.45 & 6.47 & 5.58 \\
\hline Iron & 4.26 & 5.41 & 3.89 \\
\hline Zinc & 3.17 & 4.18 & 6.38 \\
\hline Vitamin B12 & 13.9 & 18.6 & 20.2 \\
\hline
\end{tabular}

Nutrient density $=\geq 1.00$ : good source.

a Calculated using data from Table 9 and RDA table in Schönfeldt and Welgemoed (1996).

\subsection{Nutrient density and the Index of Nutritional Quantity}

Nutrient density is used for this purpose as it measures the nutrients a foodstuff provides relative to the energy it provides. The more nutrients present and the fewer kiloJoules, the higher the nutrient density. Nutrient density is calculated as follows:

\section{Amount of micronutrient present in food $\mathrm{kJ}$ content of food $x \frac{\mathrm{kJ} \mathrm{RDA}}{\mathrm{RDA} \text { of micronutrient }}$}

In Table 5 the nutrient density value for all three cooked mutton cuts are above 1 , confirming that they supply significant quantities of a range of protein, iron, zinc and vitamin $\mathrm{B}_{12}$ for a limited amount of energy. 


\section{CONCLUSION}

It is evident from this study that South African mutton (C2) provides a variety of valuable nutrients. Results indicate that nutrients vary between the raw and the cooked cut. The main cause for this change is the lost in moisture which consecutively lead to higher concentrations of the nutrients. Cooking affected mainly the protein, potassium, zinc and energy values, which were higher in the cooked meat cuts, but in addition differed between the different cooked cuts. Soluble micronutrients can also be lost during the cooking process. Although micronutrients are lost during the cooking process through leaching and solubility, South African mutton (C2) can be regarded as an important dietary source of the B vitamins, iron, and zinc. There was no significant difference in the iron values between the cooked cuts.

Large differences were apparent upon comparing the nutrient composition of a $100 \mathrm{~g}$ edible portion of the different raw and cooked cuts. During the cooking process moisture decreased in all three cuts while most heat stable nutrients increased. Vitamin B12, B3, B2 and zinc increased in all three cuts during cooking while sodium, vitamin B1 and vitamin B6 decreased in all three cuts.

Upon comparing the current result with the MRC food composition tables of 1999, it is clear that there are significant differences. The current study indicates that cooked South African mutton (C2) contain almost $30 \%$ less fat and $32 \%$ less cholesterol per cooked edible portion. These new results shows that the leg cut of mutton (C2) classifies for the heart foundation mark of approval as it contains less that $10 \mathrm{~g}$ fat per $100 \mathrm{~g}$ edible portion. New results further indicate that South African mutton (C2) are an excellent source of protein, iron, zinc and vitamin $\mathrm{B}_{3}$ as it 
makes a valuable contribution to the RDA of these nutrients for males, aged $25-50$ years when included as part of a balanced meal plan. Therefore, it can be recommended that lean meat can be consumed in moderation and should be promoted as part of a healthy balanced diet.

\section{ACKNOWLEDGEMENTS}

Thank you to the personnel of the Sensory Analysis and Human Nutrition Unit, ARC - Irene Analytical Services and the abattoir team at the ARC - ANPI, Irene, for their technical assistance that is greatly appreciated, as well as Ms MF Smith for the statistical analysis. Red Meat Research and Development Trust of South Africa (RMRDT) and the Agricultural Research Council (ARC - ANPI), Irene, provided valuable funding for the project.

\section{REFERENCES}

American Meat Science Association. (1995). Research guidelines for cookery, sensory evaluation and instrumental tenderness measurements in fresh meat. American Meat Science Association, National Livestock and Meat Board. Chicago: Illinois.

Bhattacharya, A., Banu, J., Rahman, M., Causey, J., Fernandes, G. (2006). Biological effects of conjugated linoleic acid in health and disease. Journal of Nutritional Biochemistry, (article in press), 1-22.

Corino, C., Filetti, F., Gambacorta, M., Manchisi, A., Magni, S., Pastrolli, G., Rossi, R., Maiorano, G. (2003). Influence of dietary conjugated linoleic acid (CLA) and age at slaughtering on meat quality and intramuscular collagen in rabbits. Meat Science, 66, 97103. 
Deharveng, G., Charrondiere, U.R., Slimani, N., Southgate, D.A.T., Riboli, E. (1999). Comparison of nutrients in the food composition tables available in the nine European countries participating in EPIC. European Journal of Clinical Nutrition, 53, 60-79.

Department Of Health. Draft Regulations relating to the South African Labelling and Advertising of Foodstuffs as part of the Foodstuffs, Cosmetics and Disinfectants Act, 1972. (http://www.doh.gov.za/department/dir_foodcontr.html) [s.a.].

Garnier, J., Klont, R., Plastow, G. (2002). The potential impact of current animal research on the meat industry and consumer attitude towards meat. Meat Science, 63, 79-88.

GenStat ${ }^{\circledR}$ for Windows ${ }^{\circledR}$ (7th Edition) - Introduction (Editor R.W. Payne),Published 2003 by VSN International, ISBN 1-904375-08-1

Givens, D.I. (2005). The role of animal nutrition in improving the nutritive value of animalderived foods in relation to chronic disease. Proceedings of the Nutrition Society, 64, 395402.

Greenfield, H., Southgate, D.A.T. (2003). Food composition data. Rome. Food and Agriculture Organization of the United Nations.

Hoke, I.M., Buege, D.R., Ellefson, W., Maly, E. (1999). Nutrient and related food composition of exported Australian lamb cuts. Journal of Food Composition and Analysis, 12, 97-109.

Jamora, J.J., Rhee, K.S. (1998). The uniqueness of lamb. Nutritional and sensory properties. Sheep \& Goat Research Journal, 14(1), 53-64.

Johnson, A.R. (1987). The nutrient composition of Australian meat and poultry: A preface, Food technology in Australia, 39, 183-184. 
Juarez, M., Horcada, A., Alcade, M.J., Valera, M., Mullen, A.M., Molina, A. (2007). Estimation of factors influencing fatty acid profiles in light lambs. Meat Science, unknown volume and page.

Kirton, A.H., Barton, R.A., Rae, A.L. (1962). The efficiency of determining the chemical composition of lamb carcasses. Journal of Agricultural Science, 58, 381-385.

Kruger, R., Van Der Spuy, E.H., Viljoen, A.T. (2003). Nutrition in the rural context Unit 5, $\underline{\text { In}}$ : Graduate Readings, 3:344. Fundamentals of Nutrition Security in Rural Development.

Labadarios, D., Oelofse, A. (2000). Urban Nutrition Action Workshop: Lifespan and lifestyle issues for Africa. South African Journal of Clinical Nutrition, S3.

Langenhoven, M., Kruger, M., Gouws, E., Faber, M. (1993). MRC Food composition tables, 3rd ed. Medical Research Council. Tygerberg. South Africa.

Latham, M.C. (1997). Human nutrition in the developing world. Rome. FAO.

Lawrie, R.A. (1998). Meat Science. 6th ed. Cambridge, England: Woodhead publishing limited.

Miller, D.S., Payne, P.R. (1961). Problems in the prediction of protein values of Diets: The use of food composition tables. Journal of Nutrition, 74, 413-419.

Okeudo, N.J., Moss, B.W. (2005). Interrelationships amongst carcass and meat quality characteristics of sheep. Meat Science, 69, 1-8.

Ono, K., Berry, B.W., Johnson, H.K., Russek, E., Parker, C.F., Cahill, V.R., Althouse, P.G. (1984). Nutrient Composition of Lamb of two age groups. Journal of Food Science, 49, 1233-1257. 
Park, Y., Pariza, M.W. (2006). Mechanisms of body fat modulation by conjugated linoleic acid (CLA). Food Research International, 40, 311-323.

Robinson, C.H. 1978. Fundamentals of normal nutrition. Third edition. Macmillan Publishing Co. USA. New York.

Sayed, N., Frans, Y., Schönfeldt, H.C. (1999). Composition of South African Foods: Milk \& Milk products, Eggs, Meat \& Meat products. Supplement to the MRC Food Composition Tables 1991.

Schmid, A., Collomb, M., Sieber, R., Bee, G. (2006). Conjugated linoleic acid in meat and meat products: A review. Meat Science, 73, 29-41.

Schönfeldt, H.C. (1998). Effect of age on beef quality. Ph D Thesis, University of Pretoria.

Schönfeldt, H.C., Welgemoed, C. (1996). Composition of South African beef. ISBN 1-91971701-X. South African Meat Board. Pretoria.

Snedecor, G.W, Cochran, W.G. (1980). Statistical methods (7th Ed.). Ames: Iowa State University Press, p507

Southgate, D.A.T. (1998). 15-Food composition tables and nutritional databases. In: Garrow, J.S. James, W. P. T \& Ralph A. (ed.). Human nutrition and dietetics. 10th ed. Edinburgh: Churchill Livingstone.

United Stated Department Of Agriculture. 1989. Composition of Foods: Lamb, Veal and Game Products. Agricultural Handbook number 8-17.

Van Heerden, S.M., Schönfeldt, H.C., Kruger, R. \& Smith, M.F. (2007). The nutrient composition of South African lamb (A2 grade). Journal of Food Composition and Analysis. 20, 671-680. 
Vandendriessche, F. (2008). Meat products in the past, today and in the future. Meat Science, 78, 104-113.

Whigham, L.D., Cook, M.E., Atkinson, R.L. (2000). Conjugated linoleic acid: implications for human health. Pharmacological Research, 42, 503-510.

Whitney, E.N., Rolfes, S.R. (2002). Understanding nutrition. $9^{\text {th }}$ ed. London. Wadsworth. 